Çukurova Üniversitesi Mühendislik Fakültesi Dergisi, 36(4), ss. 1073-1088, Aralık 2021

Cukurova University Journal of the Faculty of Engineering, 36(4), pp. 1073-1088, December 2021

\title{
Sorel Çimentolu Hafif Betonların Mekanik ve Yalıtım Özelliklerinin İncelenmesi
}

\author{
Hüseyin TEMIZ*1 ${ }^{* 1}$ ORCID $0000-0002-8654-103 X$ \\ Ergin TANDIRCI ${ }^{1}$ ORCID 0000-0002-1595-1330
${ }^{1}$ Kahramanmaraş Sütçü İmam Üniversitesi, Mühendislik Fakültesi, Inşaat Mühendisliği Bölümü, Kahramanmaraş

Geliş tarihi: 02.07.2021 Kabul tarihi: 10.12.2021

Atıf şekli/ How to cite: TEMIZ, H., TANDIRCI, E., (2021). Sorel Çimentolu Hafif Betonların Mekanik ve Yalıtım Özelliklerinin İncelenmesi. Çukurova Üniversitesi, Mühendislik Fakültesi Dergisi, 36(4), 1073 1088 .

\section{$\ddot{\mathbf{O} z}$}

Bu çalışmada, Sorel çimentolu hafif betonların (SÇ) bazı mekanik ve yalıtım özellikleri incelenmiştir. SÇ numunelerinin yalıtım özelliklerinde iyileştirmeler yapabilmek için SÇ karışımları içerisine; hava sürükleyici katkı (HSK), ahşap talaşı (AT), mısır koçanı talaşı (MT), Puzolanlı madde (P), Afşin-Elbistan Termik Santral uçucu külü (AEUK) katkıları ayrı ayrı ikame edilerek numuneler üretilmiştir. Numuneler, bazı mekanik testlere ve yalıtım testlerine tabi tutulmuştur. Ayrıca referans numunelerin (R) farklı ortam koşullarına karşı dirençleri incelenmiştir. Numune dayanım değerlerinin yüksekten düşüğe sırasıyla SÇ, $\mathrm{SÇ}+\mathrm{HSK}, \mathrm{SÇ}+\mathrm{P}, \mathrm{SÇ}+\mathrm{AEUK}, \mathrm{SÇ}+\mathrm{AT}$ ve SÇ+MT olduğu tespit edilmiştir. SÇ+AEUK numunelerinin çatlaması nedeniyle SÇ ve AEUK malzemelerinin birlikte kullanılmalarının uygun olmadı̆̆ gözlemlenmiştir. Suda bekletilen SÇ numunelerinin dayanımlarının zamanla düştüğü saptanmıştır. Ortam sıcaklık artışının R numunelerinin dayanımlarında $100{ }^{\circ} \mathrm{C}$ 'de artış, $500{ }^{\circ} \mathrm{C}$ ve sonrasında düşüşe neden olduğu görülmüştür.

Sonuç olarak katkı kullanılan numunelerin R numuneye göre dayanımlarında düşüş, yalıtım özelliklerinde ise bazı iyileşmelerin olduğu gözlemlenmiştir. Saptanan değerler kullanılan katkıların türüne ve oranına göre farklılık göstermiştir.

Anahtar Kelimeler: Sorel çimentosu, Hafif ağırlıklı numune, Yalıtım, Hafif agrega, Dayanım

\footnotetext{
*Sorumlu yazar (Corresponding author): Hüseyin TEMİ, htemiz@ksu.edu.tr
} 


\title{
Investigation of Mechanical and Insulation Properties of Sorel Cement Lightweight Samples
}

\begin{abstract}
In this study, some mechanical and insulation properties of Sorel cement lightweight concretes (SC) were investigated. In order to make improvements in the insulation properties of SC samples; Samples were produced by substituting air-entraining additive (HSK), wood shavings (AT), corn cob shavings (MT), Pozzolanic substance (P), Afşin-Elbistan Thermal Power Plant fly ash (AEUK) additives separately. The samples were subjected to some mechanical tests and insulation tests. In addition, the resistances of the reference samples $(\mathrm{R})$ against different environmental conditions were examined. It was determined that the sample strength values, from high to low, were SC, SC+HSK, SC+P, SC+AEUK, SC+AT and $\mathrm{SC}+\mathrm{MT}$, respectively. It has been observed that it is not appropriate to use SC and AEUK materials together due to the cracking of the SC+AEUK samples.It was determined that the strength of the SC samples kept in water decreased over time. It was observed that the increase in ambient temperature caused an increase in the strength of the R samples at $100{ }^{\circ} \mathrm{C}$ and a decrease at $500{ }^{\circ} \mathrm{C}$ and later.
\end{abstract}

As a result, it was obtained that the strength of the samples using additives decreased compared to the $\mathrm{R}$ sample, and there was some improvement in the insulation properties. The determined values differed according to the type and ratio of the additives used.

Keywords: Sorel cement, Lightweight sample, Insulation, Lightweight aggregate, Strength

\section{GíRIŞ}

Günümüzde insanın yaşamını devam ettirebilmesi için gerekli temel ihtiyaçlardan biri de enerjidir. Gelişmiş ve gelişmekte olan birçok ülkenin nüfusuna ve üretim faaliyetlerine oranla nüfus artış1, sanayileşme ve kentleşme gibi etkenlere bağlı olarak bu ülkelerin enerjiye olan gereksinimleri hızla artmaktadır. Enerjiye olan ihtiyacın her geçen gün artması, enerji tüketimini de paralel olarak artırmaktadır.

Türkiye enerjide dişa bağımlı olan ülkelerden biridir. Ülkemizde son yıllarda hızla artan inşaat faaliyetleri ile birlikte binalarda tüketilen enerji miktarı da katlanarak artmaktadır [1]. Artan enerji tüketiminin; ülkelerin ekonomileri yanında insan ve çevre sağlığına da ciddi anlamda zarar vermesinden dolayı enerji tüketimini azaltmaya yönelik bu enerjinin muhafaza edilmesi ve tasarrufu üzerine yapılan çalışmalar son dönemde hız kazanmıştır.

Modern dünyanın ihtiyaçlarına uygun olarak, çevre kirliliğini azaltmak, endüstriyel atıkları değerlendirmek ve bu atıkların kullanımını yaygınlaştırmak için son yıllarda bu konu ile ilgili kapsamlı araştırmalar yapılmaktadır. Yeterince değerlendirilmeyen katkı maddelerinin yap1 malzemesi üretiminde kullanılması halinde bazı mekanik ve yalıtım özelliklerini etkilediği bilinmektedir. $\mathrm{Bu}$ yolla faydalı atık bertarafina katkıda bulunulabilir.

Magnezyum oksiklorür çimentosu (Sorel çimentosu) 1867'de Fransız araştırmacı Stanislaw Sorel tarafından keşfedilmiştir. $\mathrm{Bu}$ sebeple magnezyum oksiklorür çimentosu Sorel ismini almıştır. SÇ bazlı malzemeler, SÇ’nin normal Portland çimentosuna kıyasla bazı üstün özellikleri bulunması sebebiyle son zamanların araştırma konusu olarak ilgi odağı haline gelmiştir [2].

Sorel çimentosu, magnezyum oksit $(\mathrm{MgO})$ ve magnezyum klorür $\left(\mathrm{MgCl}_{2}\right)$ çözeltisinin farklı oranlarda karıştırılmasıyla elde edilen özel bir çimentodur. SÇ’nin üretiminde kullanılan magnezya $(\mathrm{MgO})$, deniz sularından veya ham manyezit mineralinden $\left(\mathrm{MgCO}_{3}\right)$ elde edilir. Manyezit minerali ise doğada bulunduğu şekilde 
doğrudan Sorel çimentosu karışımına girmez. Manyezit minerali bazı işlemlerden geçirildikten sonra Sorel çimentosu üretiminde kullanılabilmektedir. Manyezit $\left(\mathrm{MgCO}_{3}\right)$ mineralinden elde edilen magnezya, $750-1000{ }^{\circ} \mathrm{C}$ sıcaklıkları arasında kalsine edilerek meydana gelip kalsinasyon işlemi döner ya da dik firınlarda gerçekleştirilmektedir. Kalsine edilen Manyezit $\left(\mathrm{MgCO}_{3}\right)$ daha sonra farklı boyutlara getirilip öğütülür. Bu işlem anında manyezitte bulunan $\mathrm{CO}_{2}$ ayrılarak $\mathrm{MgO}$ elde edilir [3] (Eşitlik 1).

$\mathrm{MgCO}_{3} \rightarrow \mathrm{MgO}+\mathrm{CO}_{2}$

Elde edilen $\mathrm{MgO}$, su içinde $\mathrm{MgCl}_{2}$ içeren bir magnezyum klorür çözeltisi ile karıştırılır (Eşitlik 2).

$\mathrm{MgO}+\mathrm{MgCl}_{2}+\mathrm{H}_{2} \mathrm{O} \rightarrow 2 \mathrm{Mg}(\mathrm{OH}) \mathrm{Cl}$

SÇ’nin kullanım alanları olarak, otoyol yüzeylerinin yanı sıra sıva, yangına dayanıklı kaplamalar ve kalıplanmış çimento nesneleri gibi benzeri uygulamalarda hızlı priz alan bir çimento olarak kullanılır. Ring ve Ping (2007) yapmış olduğu çalışmasında katı magnezyum oksitin ( $\mathrm{MgO})^{\prime}$ 'in magnezyum klorür $\left(\mathrm{MgCl}_{2}\right)$ ve su ile karıştırılması ile SÇ elde etmiştir. Elde ettikleri çimentonun hızlı bir şekilde prizini aldığını gözlemlemişlerdir [4].

Daha çevreci bir yaklaşımla çevrenin korunmasına duyulan ihtiyaç konusunda giderek artan farkındalık nedeniyle, SÇ içeren araştırma konuları son zamanların araştırma konuları içerisinde artan bir ilgi odağı halini almıştır. Chau ve Li (2008) çalışmasındaki kapsamlı mikroskobik gözlemler, SÇ'nin kristal fazlarının genel olarak nano boyutlu küçük taneciklerden oluşan granüler bir yüzeyle farklı formlarda demetlenmiş iğne şeklinde kristaller olduğunu göstermektedir. Çimento hamurunun yüksek basınç dayanımına sahip masif ve yoğun mikro yapısında demetlenmiş iğne şeklindeki kristal izleri de gözlemlenmiştir [5].

Shahbazı ve Sadeghı (2016) çalışmasında, SÇ ile ürettikleri numunelerin su direncini ve basınç dayanımlarını incelemişlerdir. Ayrıca hızlı priz alan SÇ karışımları için bazı katkı maddeleri yardımıyla çimento priz süresini uzatmak istemişlerdir. Çalışmadaki sonuçlar, çimento içerisine ilave edilen bazı katkı maddelerinin (Cam elyafı, silisyum karbür tozu) çimentonun mekanik mukavemetini ve priz süresini artırdığını göstermektedir. Bununla beraber suya karş1 dayanımı düşük olan SÇ numunelerinin karışım içerisine bazı katkı maddelerinin eklenmesiyle su direncinin arttırılabilir olduğu görülmüştür [6].

İnşaat sektörünün sürekli gelişmesiyle birlikte düşük maliyetli, dayanıklı, hafif, uzun kullanım süresine sahip kompozit yapı malzemelerinin önemi gün geçtikçe artmaktadır. Gürbüz ve Kork (2020) çalışmasında kompozit yap1 malzemelerinden olan magnezyum oksit levhaları ele almışlardır. MgO levhaların kullanım alanı açısından çeşitli iklim koşullarına uygun kimyasal ve fiziksel bir yapıya sahip olduğu söylenebilir ve bu levhalar inşaat sektöründe hemen her alanda kullanılabilecek kompozit panel olarak öne çıkmaktadır. Geleneksel olarak kullanılan yapı levhalarının yerine $\mathrm{MgO}$ levhaların tercih edilmesi yangına ve darbeye dayanımının yüksek ve çevre dostu olmasından dolayı tercih edilebilir. Ancak $\mathrm{MgO}$ levhaların üretimi diğer yapı levhalarına kıyasla hazırlanışında sık1 kontrol gereksinimi, aşırı yüksek nemli ortamlarda deformasyona uğraması ve özellikle yüksek maliyetinden ötürü dünyada kullanımının olması gerektiği kadar yaygınlaşmadığı görülmektedir. Yapılan araştırma ve deneysel çalışmalar sonucunda magnezyum oksit levhaların diğer kompozit yapı malzemelerinden daha kullanışlı olduğu gözlemlenmiştir [7].

Bu çalışmada SÇ bağlayıcılı ve hafif agregalarla üretilen numunelerin mekanik ve yalıtım özellikleri incelenmiştir. Araştırılan numuneler referans numunesi SÇ ile ve diğer numuneler SÇ içerisine P, HSK, AEUK, AT ve MT malzemelerinin eklenmesi ile hazırlanmıştır. Numunelerin; eğilme-basınç dayanımı, 1sı iletim katsayısı, ultrases geçiş hızı, birim hacim ağırlık, su emme ve görünür gözeneklilik, hacimsel genleşme, alkali silika reaksiyonu (ASR), yüzey alanı analizi (BET) incelenmiştir. Ayrıca, su ve sıcaklığın etkisine maruz birakılan $\mathrm{R}$ numunelerin gösterdiği reaksiyon incelenmiştir. 


\section{MATERYAL VE METOT}

\subsection{Materyal}

Magnezyum oksit (MgO): SÇ’nin ana hammaddelerinden biri olan magnezyum oksidin yoğunluğu $3,12 \mathrm{~g} / \mathrm{cm}^{3}$ olup kimyasal ve fiziksel analiz sonuçları Çizelge 1 ve Çizelge 2'de verilmiştir. MgO Şekil 1a'da görülmektedir.

Çizelge 1. Magnezyum oksit kimyasal analiz sonuçları [8]

\begin{tabular}{|c|c|}
\hline Kimyasal Özellikler & Analiz Sonuçları (\%) \\
\hline $\mathrm{MgO}$ & 85 \\
\hline $\mathrm{CaO}$ & 2,5 \\
\hline $\mathrm{SiO}_{2}$ & 5,5 \\
\hline $\mathrm{Fe}_{2} \mathrm{O}_{3}$ & 1,25 \\
\hline $\mathrm{Al}_{2} \mathrm{O}_{3}$ & 0,1 \\
\hline Kızdırma Kayb1 & 3 \\
\hline
\end{tabular}

Çizelge 2. Magnezyum oksit fiziksel analiz sonuçlar1 [8]

\begin{tabular}{|l|c|c|c|}
\hline Elek açıklığ $(\mu \mathrm{m})$ & $300 \mu \mathrm{m}$ & $150 \mu \mathrm{m}$ & $-150 \mu \mathrm{m}$ \\
\hline Yüzde geçen & $100 \%$ & $\% 5 \max$ & $95 \%$ \\
\hline
\end{tabular}

Magnezyum klorür (MgCl $\mathbf{2})$ : Kristal şeklindeki $\mathrm{MgCl}_{2}$ deniz suyundan ya da manyezit $\left(\mathrm{MgCO}_{3}\right)$ mineralinden elde edilir. Magnezyum klorürün molar ağırlığı 203,31 g/mol ve yoğunluğu $1,569 \mathrm{~g} / \mathrm{cm}^{3}$ 'tür. $\mathrm{MgCl}_{2}$ kimyasal özellikleri Çizelge 3'te belirtilmiştir. $\mathrm{MgCl}_{2}$ Şekil 1 b'de görülmektedir.

Çizelge 3. $\mathrm{MgCl}_{2}$ kimyasal analiz sonuçları

\begin{tabular}{|l|c|c|c|c|}
\hline Kimyasal özellikler & $\mathrm{MgCl}_{2}$ & $\mathrm{CaCl}_{2}$ & $\mathrm{NaCl}$ & $\mathrm{KCl}$ \\
\hline Oranları $(\%)$ & 46,5 & 21,12 & 0,51 & 0,31 \\
\hline
\end{tabular}

\begin{tabular}{|l|c|c|c|c|}
\hline Oranlar1 (\%) & 46,5 & 21,12 & 0,51 & 0,31 \\
\hline
\end{tabular}

Su: Karıșımlarda şebeke suyu kullanılmış olup Kahramanmaraş Sütçü İmam Üniversitesi Mühendislik Fakültesi İnşaat Mühendisliği Bölümü laboratuvarından temin edilmiştir.

Uçucu kül: Çalışmada Afşin Elbistan Termik Santralından temin edilen uçucu kül (AEUK) kullanılmıştır. Bu külün yoğunluğu $2,15 \mathrm{~g} / \mathrm{cm}^{3}$ 'tür ve kimyasal analiz sonuçları Çizelge 4'te verilmiştir. AEUK Şekil 1c'de görülmektedir.
Çizelge 4. AEUK kimyasal analiz sonuçları [9]

\begin{tabular}{|c|c|}
\hline Kimyasal özellikler & Analiz sonuçları (\%) \\
\hline $\mathrm{SiO}_{2}$ & 18,27 \\
\hline $\mathrm{Al}_{2} \mathrm{O}_{3}$ & 9,16 \\
\hline $\mathrm{Fe}_{2} \mathrm{O}_{3}$ & 3,26 \\
\hline $\mathrm{CaO}$ & 53,44 \\
\hline $\mathrm{MgO}$ & 1,74 \\
\hline $\mathrm{K}_{2} \mathrm{O}$ & 0,38 \\
\hline $\mathrm{Na}_{2} \mathrm{O}$ & 0,19 \\
\hline $\mathrm{SO}_{3}$ & 11,4 \\
\hline Kizdirma kayb1 & 2,12 \\
\hline
\end{tabular}
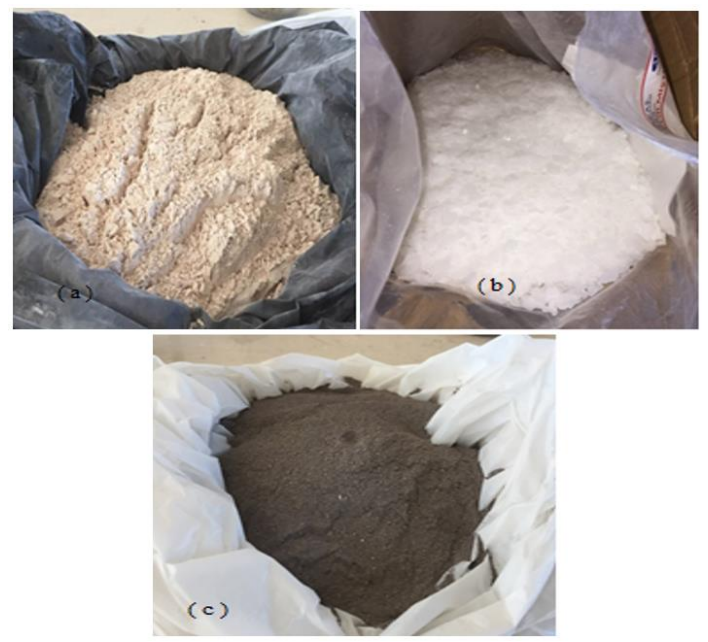

Şekil 1. a) Magnezyum oksit, b) Magnezyum klorür, c) Afşsin-Elbistan uçucu külü

Puzolanik madde (Bims): Araştırmada yararlanılan puzolan (bims) boşluklu, süngerimsi bir yapıya sahip olup volkanik olaylar sonucu meydana gelmektedir. Fiziksel ve kimyasal etkilere karşı dayanıklıdır. Gözenekli ve camsı bir yapıya sahip volkanik bir kayaç olan puzolan, oluşumu esnasında bünyesindeki gazların hızlı bir şekilde bünyeyi terk etmesi ve ani soğuması sebebiyle sayısız gözenek barındırır. Puzolanik maddenin gözenekleri arası genellikle birbirleriyle bağlantısız oluşu ve boşluklu bir yapı barındırması sebebiyle, permeabilitesi düşük, 1sı ve ses yalıtımı oldukça yüksektir [10]. Yapılan bu deneysel çalışmada karışım içerisine ikame edilen puzolanik madde ile daha düşük birim hacim ağırlığına ve daha iyi 1sı ve su yalıtımı değerlerine sahip bir malzeme elde edilmesi amaçlanmıştır. Puzolanik madde Şekil 2a'da görülmektedir. 
Hava sürükleyici katkı: $\mathrm{Bu}$ tez çalışmasında hava sürükleyici katk1 olarak MasterAir ${ }^{\circledR} 200$ kullanılmıştır. MasterAir ${ }^{\circledR}$ 200, yağ alkolü ve amonyum tuzu esaslı bir katkı maddesidir. MasterAirß 200 karışım içerisine kontrollü hava sürükleyerek kalıcı, küçük ve optimum aralıklı hava kabarcıkları oluşturan ve karışımın donmaçözülme döngüsüne karşı dayanıklılığını artıran, hava sürükleyici katkı malzemesidir [11]. Bu katkı maddesinin karışım içerisine ikame edilmesiyle daha düşük birim hacim ağırlıklı ve daha iyi ısı ve su yalıtımı değerlerine sahip bir malzeme elde edilmesi amaçlanmıştır.

Mısır koçanı talaşı: Ülkemizde geniş bir ekim alanı bulunan mısırın ortasında yer alan genellikle sert bir yapıya sahip parçaya mısır koçanı denilmektedir. $\mathrm{Bu}$ çalışmada mısırın atık ürünü sayılan mısır koçanının yalıtım malzemesi olarak değerlendirilebilmesi araștırılmış olup bu atık ürünün değerlendirilmesiyle çevreye ve ülke ekonomisine artı bir kazanç sağlanmak amaçlanmıştır. Öğütülmüş mısır koçanı talaşı Şekil 2b'de görülmektedir.

Ahşap talaşı: Son zamanlarda hammaddelerin verimli kullanılması ile beraber insanların çevreye olan duyarlılığındaki artış ve atık malzemelerin geri dönüştürülebilmesi üzerine yapılan araştırmalar oldukça yoğunlaşmıştır. Bu atık malzemelerin önemli bir bölümünü orman endüstrisi atıkları oluşturması sebebiyle bu çalışmada ayrıca kereste veya mobilya fabrikalarında açığa çıkan ahşap talaşı atıklarının yalıtım malzemesi olarak değerlendirilebilmesi incelenmiştir. Şekil 2c'de ahşap talaş1 görülmektedir.

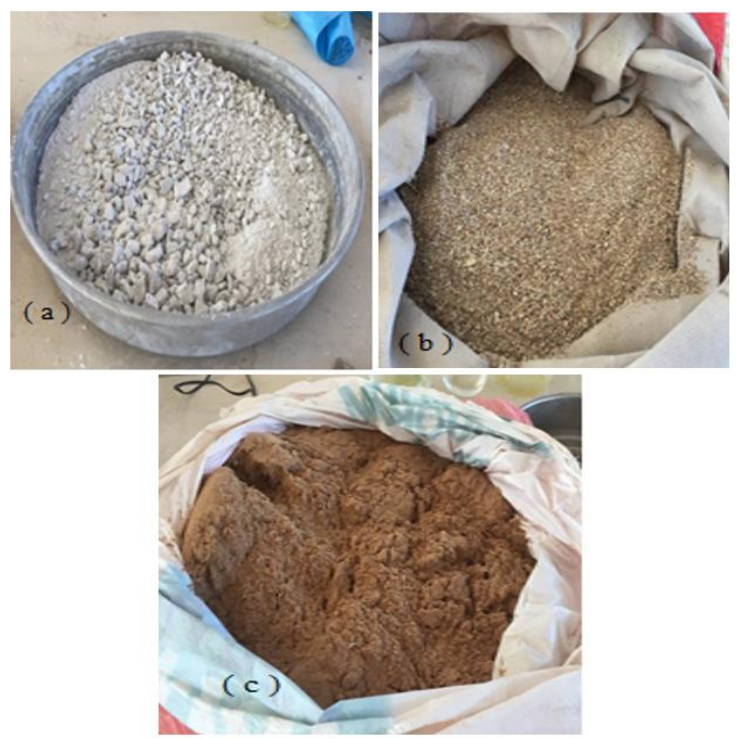

Şekil 2. a) Puzolanik madde, b) Mısır koçanı talaşı, c) Ahşap talaşı

\subsection{Metot Numunelerin Hazırlanması ve Karışım Oranları}

$\mathrm{Bu}$ çalışmada bağlayıcı olarak SÇ kullanılmıştır. SÇ’nin karışımına giren $\mathrm{MgO}$ ve $\mathrm{MgCl}_{2}$ oranlarının belirlenmesinde 5 nolu referans esas alınmıștır [12]. Buna göre SÇ'nin karışımı \%76 $\mathrm{MgO}+\% 24 \mathrm{MgCl}_{2}$ ' den meydana getirilmiştir. $\mathrm{R}$ numunesi, önce $\mathrm{MgCl}_{2}+$ suyun karıştırılmasıyla elde edilen çözeltiye, $\mathrm{MgO}$ eklendikten sonra çimento mikseri ile yaklaşık 3-5 dakika karıştırılarak hazırlanmıştır. Üretilen numunelerin isimleri ve karışım miktarları Çizelge 5'te verilmiştir. $\mathrm{R}$ numunesine $\% 1$ oranında HSK ilave edilerek numuneler üretilmiştir. Diğer numuneler $\mathrm{P}$, AEUK, MT ve AT katkıları ilave edilerek üretilmiştir. 
Çizelge 5. Üretilen numunelerin karışım miktarları

\begin{tabular}{|l|c|c|c|c|c|c|c|}
\hline \multirow{2}{*}{ Numune ismi } & \multicolumn{7}{|c|}{ Miktarlar (g) } \\
\cline { 2 - 8 } & SÇ & Su & HSK & P & AEUK & MT & AT \\
\hline R & 1,740 & 320 & - & - & - & - & - \\
\hline SÇ+HSK & 1700 & 300 & 17 & - & - & - & - \\
\hline SÇ+P & 400 & 495 & - & 400 & - & - & - \\
\hline SÇ+AEUK & 980 & 420 & - & - & 420 & - & - \\
\hline SÇ+MT & 200 & 420 & - & - & - & 200 & - \\
\hline SÇ+AT & 160 & 405 & - & - & - & - & 160 \\
\hline
\end{tabular}

Hamur numunelerin priz başlama ve prizin sona erme sürelerinin tayini ile hacimsel genleşme değerlerinin saptanmasında TS EN 196-3 standard 1 esas alınmıştır [13]. Şekil 3a ve b'de sırasıyla Vicat cihazı ile yapılan priz süresi ölçüm işlemi ve hacimsel genleşme saptanması görülmektedir.

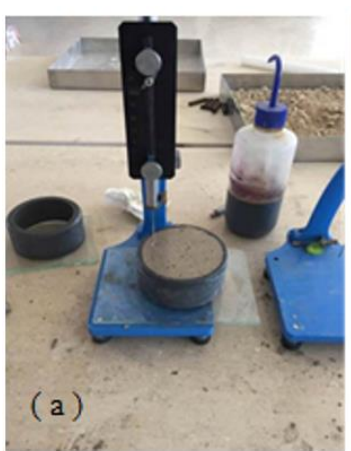

Şekil 3. (a) Priz süresi tayini, genleşmenin bulunması

Karışımların birim hacim ağırlık değerlerini bulmak için her karışımdan üç adet 10x10x10 cm boyutunda küp numuneler alınmıştır. 28 günlük numuneler TS EN 772-13 standardı esas alınarak birim hacim ağırlık deneylerine tabi tutulmuştur [14]. Küp numunelerin $0,1 \mathrm{~g}$ hassas terazide tartılma işlemi Şekil 4a'da görülmektedir.

Karışımların su emme ve görünür gözeneklilik değerlerini bulmak için her karışımdan üç adet $10 \times 10 \times 10 \mathrm{~cm}$ boyutunda küp numuneler alınmıştır. 28 günlük numuneler TS EN 993-1 standardı esas alınarak su emme ve görünür gözeneklilik deneylerine tabi tutulmuştur [15].
Küp numunelerin etüvde kurutma işlemi Şekil 4b'de görülmektedir.

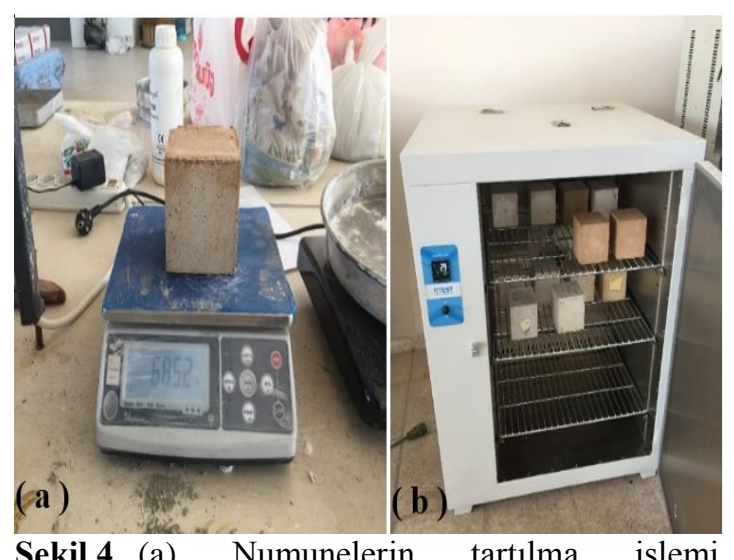

Şekil 4. (a) Numunelerin tartılma ișlemi, (b) Numunelerin etüvde kurutulma işlemi

Karışımların eğilme ve basınç dayanımlarını bulmak için her karışımdan 6 adet $4 \times 4 \times 16 \mathrm{~cm}$ boyutunda harç prizma numuneleri hazırlanmıştır. Hazırlanan numuneler deney yaşlarına kadar kür edilmişlerdir. Ayrıca SÇ numunelerinin 1sıya karşı dirençlerini saptamak amacıyla alınan numuneler oda sicaklığ $1,100{ }^{\circ} \mathrm{C}, 500{ }^{\circ} \mathrm{C}, 1000{ }^{\circ} \mathrm{C}$ sicaklıkta ve kür tankı olmak üzere 5 farklı ortam koşullarında bekletilmiştir. Tüm bu numunelerin her karışımından 3 adet 7 günlük ve 3 adet de 28 günlük olarak test edilmek üzere toplam altı adet numune alınmış ve bu numuneler TS EN 196-1 standardı esas alınarak eğilme ve basınç dayanımı deneylerine tabi tutulmuştur [16]. Şekil 5a ve b'de sırasıyla eğilme ve basınç dayanımı deneyi uygulaması görülmektedir. 


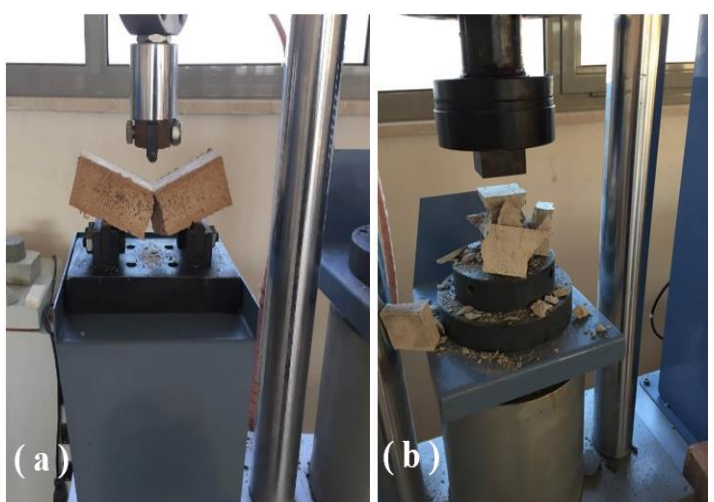

Şekil 5. (a) Eğilme dayanımı deneyi, (b) Basınç dayanımı deneyi

Karışımların boy değişimlerinin incelenmesi için hızlandırılmış yöntemlerden ASTM C1260 standardı esas alınmıştır [17]. Bu test yöntemi için her karışımdan üç adet $25 \times 25 \times 285 \mathrm{~mm}$ boyutunda prizma numuneler üretilmiştir. Alınan numuneler 14 gün $\% 1 \mathrm{Na}(\mathrm{OH})$ çözeltili suda kür edildikten sonra teste tabi tutulmuşlardır. Prizma çubukların boy ölçüm işlemi Şekil 6a'da görülmektedir.

Karışımların ultrases geçiş hızı değerlerini bulmak için her bir karışımdan üç adet 10x10x10 cm boyutunda küp numuneler alınmıştır. Alınan numuneler 28 gün oda sicaklığında bekledikten sonra ASTM C 597-16 standardı esas alınarak ultrases geçiş hızı testine tabi tutulmuştur [18]. Alınan küp numunelerin ultrases geçiş hızı ölçüm işlemi Şekil 6b'de görülmektedir.
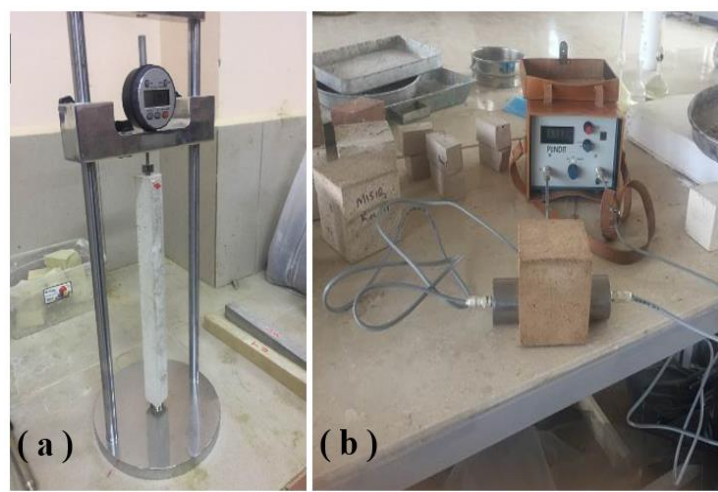

Şekil 6. (a) Numunelerin boy ölçüm işlemi, (b) Ultrases geçiş hızı ölçüm işlemi
Karışımların 1sı iletim katsayısı değerlerini bulmak için hazırlanan karışımlardan 20x20x5 cm boyutunda prizma numuneler alınmıştır. Alınan numuneler 28 gün oda sicaklığında bekledikten sonra ASTM 1113-90 standardı esas alınarak Sıcak Tel Yöntemi ile çalışan Kem QTM 500 markalı termal iletkenlik katsayısı ölçüm cihazı kullanılarak 1sı iletim katsayısının belirlenmesi için teste tabi tutulmuştur [19]. Prizma numunelerin 1s1 iletim katsayısı ölçüm işlemi Şekil 7a'da görülmektedir.

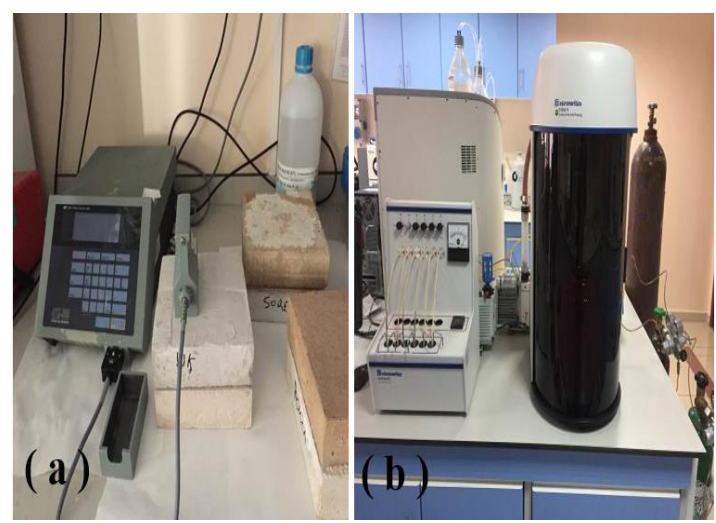

Şekil 7. (a) Isı iletim katsayısı ölçüm işlemi, (b) BET yüzey alanı ölçüm işlemi

BET yüzey alanı analizi için altı farklı karışımdan alınan numuneler ögütülerek toz hale getirilmiştir. Toz hale getirilen numunelerin BET yüzey alanı ölçüm analizi, Kahramanmaraş Sütçü İmam Üniversitesi Merkez Laboratuvarında bulunan Micromeritics Tristar II marka BET yüzey alanı ölçüm cihazı kullanılarak gerçekleştirilmiştir. Numunelerin BET yüzey alanı ölçüm işlemi Şekil 7b'de verilmiştir.

\section{BULGULAR VE TARTIŞMA}

\subsection{Priz Başlangı̧̣ ve Bitiş Süreleri}

Hazırlanan altı farklı karışımın priz başlangıç ve bitiş süresi değerleri Şekil 8'de verilmiştir. Şekil 8'deki priz süreleri üç adet deneyin ortalaması alınarak bulunmuştur. 


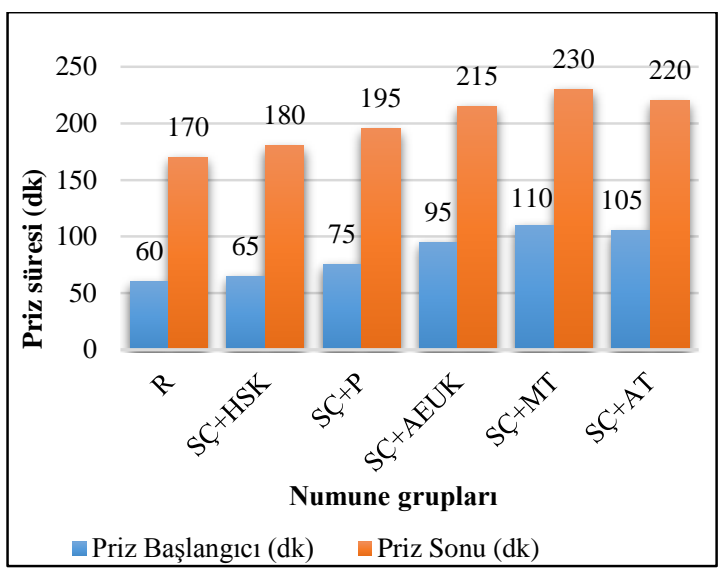

Şekil 8. Priz başlangıç ve bitiş süreleri

Şekil 8 incelendiğinde $\mathrm{R}$ hamurunun priz başlangıç ve bitiş sürelerinin daha kısa olduğu görülmektedir. $\mathrm{R}$ hamuruna göre karışıma \%1 oranında HSK katılması priz başlangıç ve bitiş sürelerini sırasıyla $\% 8$ ve $\% 6$ uzatmıştır. Aynı şekilde karışıma giren P, AEUK, MT maddeleri priz başlangıç ve bitiş süresini uzatmıştır. Uzama süreleri sırasıyla P için \%25 ve \%15; AEUK'de $\% 58$ ve $\% 27$; MT'da $\% 83$ ve $\% 35$; AT'da $\% 75$ ve $\% 29$ olmuştur.

Austin ve Daniel (1949), Smith-Johannsen (1982), Ring ve Ping (2007), Öztürk ve arkadaşları (2008), Santra ve arkadaşları (2009) yaptıkları çalışmalarda SÇ ile hazırlanan numunelerin prizlerini oldukça hızlı bir sürede aldıkları görülmüştür [20,21,4,22,23]. Shahbazı ve Sadeghı (2016) çalışmasında SÇ içerisine ilave edilen katkı maddelerinin çimento priz süresine etkisini incelemiş ve bu ilave edilen katkı maddelerinin priz sürelerini arttırdığını gözlemlemiştir [6].

Elde edilen bulguların literatür ile tutarlı olduğu; bu bulgulara göre referans numunelerin priz başlangıç ve bitiş sürelerinin oldukça kısa olduğu, karışım içerisine ikame edilen katkı maddesinin türüne göre priz sürelerinin uzadığı görülmüştür.

\subsection{Hacimsel Genleşme Değerleri}

Hazırlanan karışımların hacim sabitliği (genleşme) tayini sonuçları Şekil 9'da verilmiştir. Hacimsel genleşme değerleri üç sonucun ortalamasıdır.

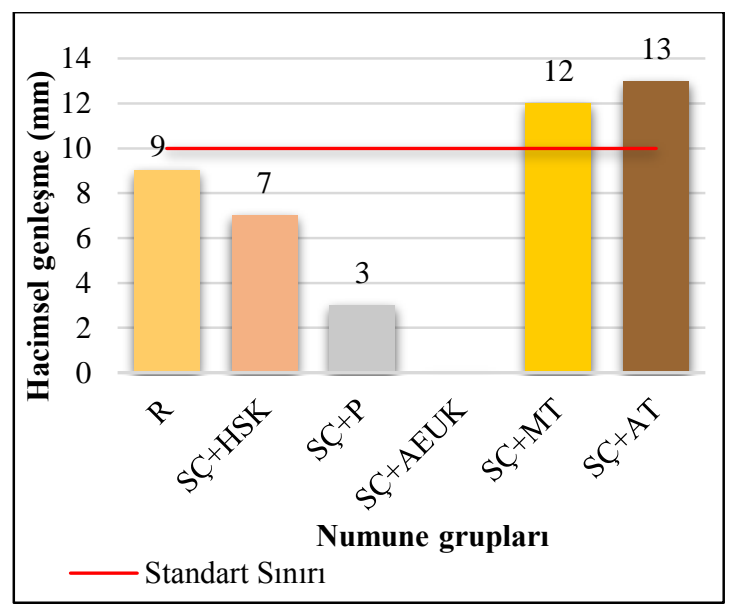

Şekil 9. Hacimsel genleşme değerleri

Şekil 9 incelendiğinde $\mathrm{R}$, SÇ+HSK ve $\mathrm{SÇ}+\mathrm{P}$ numunelerinin genleşme değerleri TS EN 196-3 standardında belirtilen $10 \mathrm{~mm}$ sınır değerinin altında kaldığı görülmüştür [13]. P katkısının genleşme miktarını azaltmasına, P'nın boşluklu yapısının neden olduğu düşünülmektedir. HSK katkısının genleşme miktarını yaklaşık \%22, P maddesinin ise yaklaşık \%67 azalttığı görülmüştür. MT ve AT maddeleri, karışımda bulunan suyun önemli bir kısmını absorbe ederek şişmesi sebebiyle standartta öngörülen $10 \mathrm{~mm}$ sınır değerinin üzerinde çıkmasına neden olmuşlardır. Zhengyuan (1993) çalışmasında SÇ ile üretilen karışımların sertleşmesi sırasında numunelerde sürekli hacim artışı sorunlarının olduğu görülmüş ve bu sorunun ise karışım için ekstra harmanlama sistemi geliştirilmesiyle çözülebileceğini belirtmiştir [24].

SÇ içerisine AEUK ilave edilmesiyle üretilen numunenin su ile temasından bir süre sonra dağıldığ́ görülmüş ve bu sebeple genleşme miktarı ölçülememiştir.

\subsection{Eğilme ve Basınç Dayanımı Tayini}

Numunelerin eğilme dayanımı sonuçları Şekil 10, basınç dayanımı sonuçları Şekil 11'de verilmiştir. Eğilme dayanımı değerleri üç değerin, basınç dayanımı değerleri ise altı değerin ortalamasıdır. 


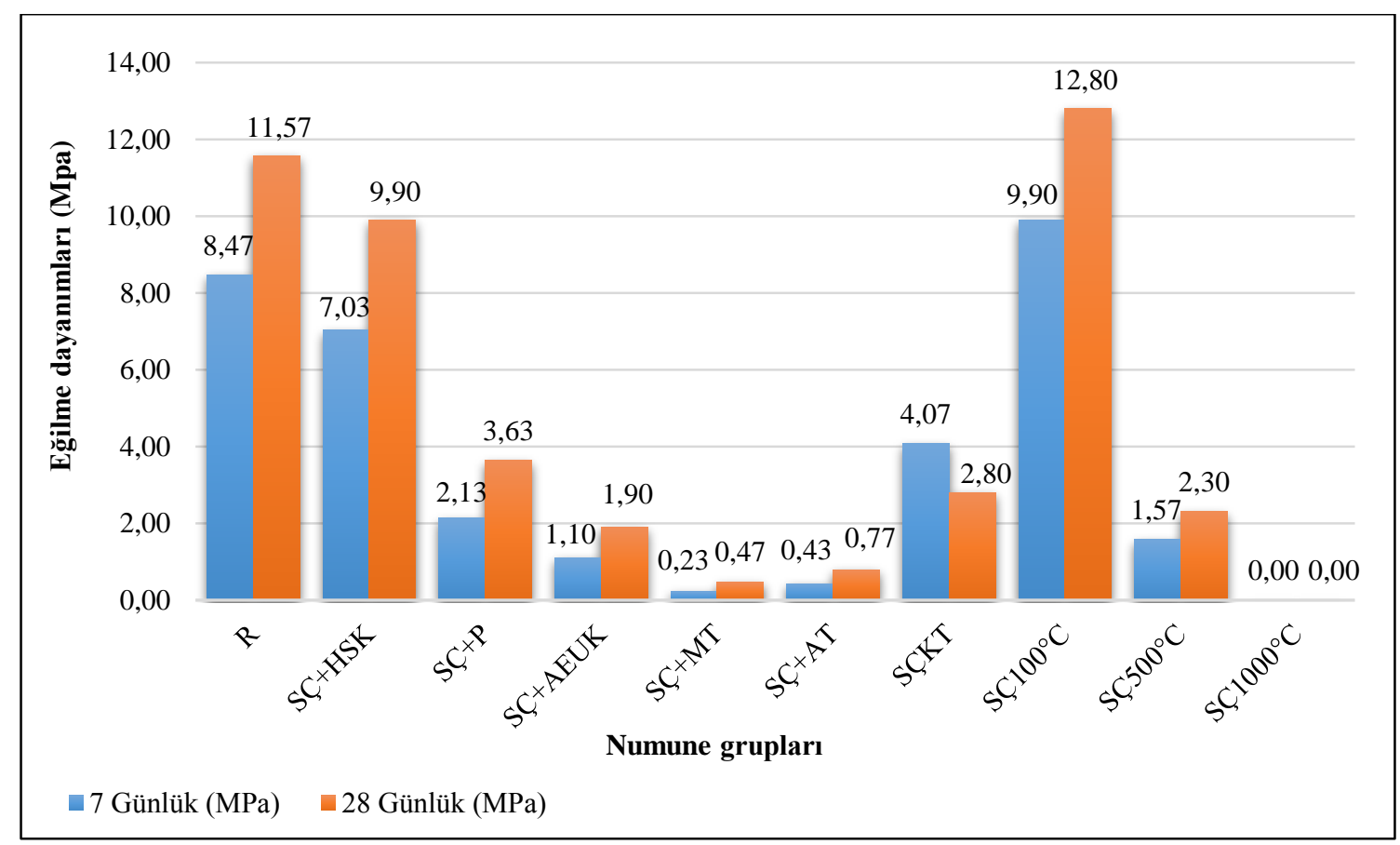

Şekil 10. 7 ve 28 günlük prizma numunelerin eğilme dayanımları

Şekil 10'da verilen değerler incelendiğinde 7 günlük eğilme dayanımlarında en yüksek dayanım $\mathrm{R}$ numunesinde $8,47 \mathrm{MPa}$, en düşük dayanım ise $\mathrm{SÇ}+\mathrm{MT}$ numunesinde $0,23 \mathrm{MPa}$ bulunmuştur. R numunesine en yakın dayanım SÇ+HSK numunesinde 7,03 $\mathrm{MPa}$ elde edilmiştir. 28 günlük numunelerin eğilme dayanım değerleri de 7 günlük numunelerin eğilme dayanımı değerlerine benzerlik göstermiştir. Buna göre en yüksek dayanım $\mathrm{R}$ numunesinde 11,57 $\mathrm{MPa}, \mathrm{R}$ 'nin dayanımına en yakın SÇ+HSK numunesinde 9,9 $\mathrm{MPa}$ bulunmuştur. Bu grupta en düşük eğilme dayanımı değeri SÇ+MT numunesinde 0,47 MPa'dır. R numunesinin 28 günlük eğilme dayanımı, 7 günlüklere göre $\% 37$ artmıştır. Numunelerin yaşlarının artmasıyla eğilme dayanımları artmıştır. SÇ+P numunesinin 7 ve 28 günlük eğilme dayanımları sırasıyla $2,13 \mathrm{MPa}$ ve 3,63 MPa'dır. Bu dayanımların R'nin dayanımına göre sırasıyla \%75 ve \%69 azaldığ1 görülmüştür. SÇ+AEUK numunesinin 7 ve 28 günlük eğilme dayanımlarının sirasıyla $1,10 \mathrm{MPa}$ ve $1,90 \mathrm{MPa}$ olduğu ve $\mathrm{R}$ numunesine göre sirasiyla $\% 87$ ve \%84 azaldığı görülmüştür. Şekil 10'da SÇ numunesinin oda sicaklığında (R), kür tankında (SÇKT) ve $100{ }^{\circ} \mathrm{C} \quad\left(\mathrm{SÇ} 100{ }^{\circ} \mathrm{C}\right), \quad 500{ }^{\circ} \mathrm{C}$ (SÇ $\left.500{ }^{\circ} \mathrm{C}\right), \quad 1000{ }^{\circ} \mathrm{C} \quad\left(\mathrm{SÇ} 1000^{\circ} \mathrm{C}\right)$ yüksek sıcaklıklı etüvde bekletilen numunelerin eğilme dayanımları incelendiğinde diğer numunelerin aksine su içinde bekletilenlerin 7 günde 28 günlüklere göre daha yüksek çıktığı saptanmıştır. $\mathrm{Bu}$ değerler sirasiyla 4,07 ve 2,8 $\mathrm{MPa}$ dır. 28 günlük numunenin 7 güne göre düşüş oranı $\% 31$ dolayındadır. $\mathrm{Bu}$ sonuç $\mathrm{SÇ}$ numunelerinin su içinde dayanım kaybettiğini göstermektedir. En yüksek eğilme dayanımı $100{ }^{\circ} \mathrm{C}$ bekletilen numunelerde elde edilmiştir. 7 ve 28 günlük dayanım değerleri sirasıyla $9,9 \mathrm{MPa}$ ve 12,8 MPa'dır. 28 günlük numunelerin eğilme dayanımları 7 güne göre yaklaşık \%29 artmıştır. $500{ }^{\circ} \mathrm{C}$ 'de çok küçük değerler elde edilirken, $1000{ }^{\circ} \mathrm{C}$ 'deki numuneler dağılmış ve dayanım bulunamamıştır. 


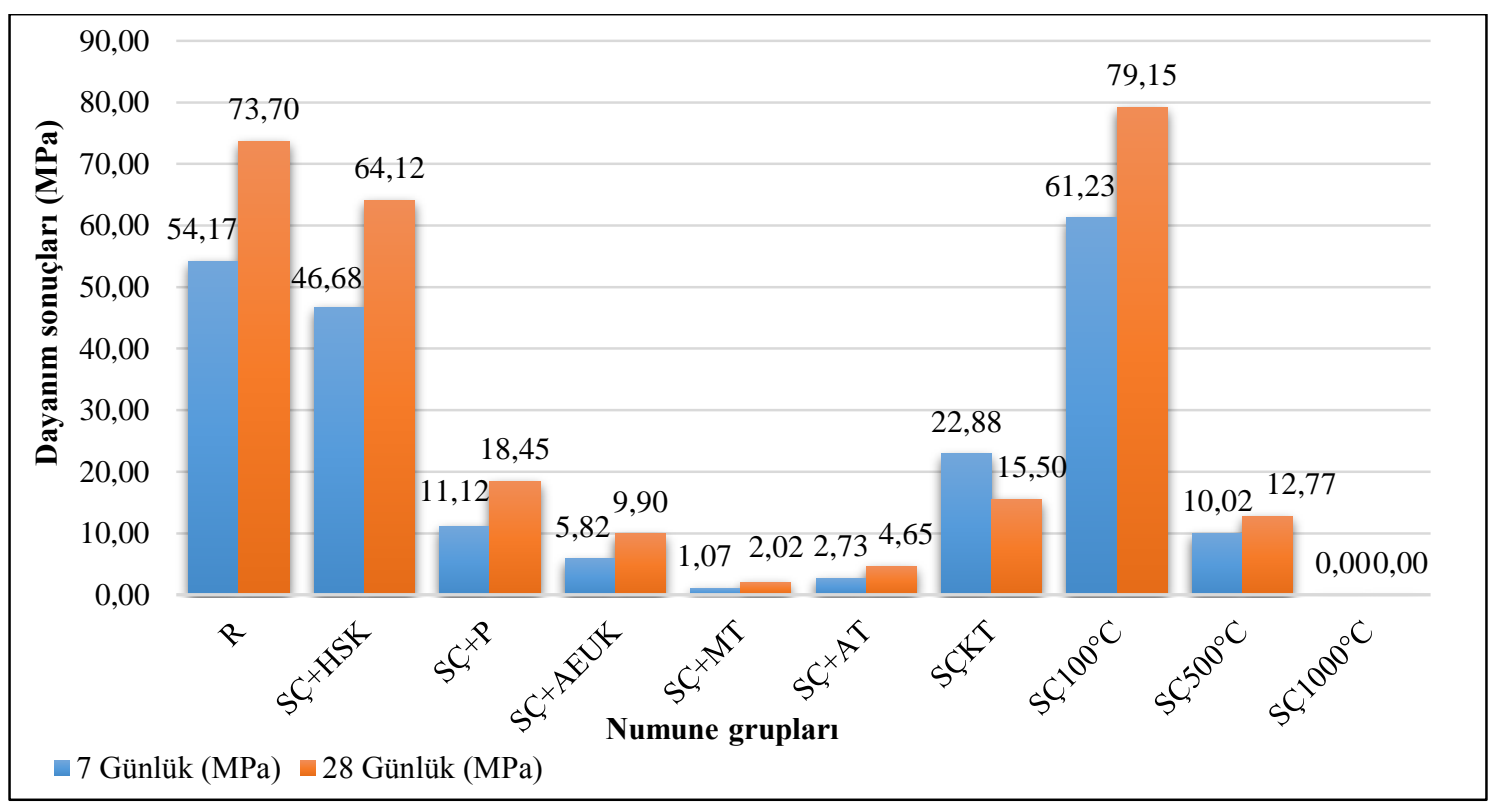

Şekil 11. 7 ve 28 günlük prizma numunelerin basınç dayanımları

Şekil 11'de verilen basınç dayanımları incelendiğinde sonuçların eğilme dayanımlarında meydana gelen değişimlere benzediği anlaşılmaktadır. 7 günlük $\mathrm{R}$ numunesinin basınç dayanımı 54,17 $\mathrm{MPa}$ iken 28 günlük numunede $73,7 \mathrm{MPa}$ olmuştur. 28 günlük $\mathrm{R}$ numunelerinin 7 günlüklere göre artış oranı \%36'dır. $\mathrm{R}$ numunesine en yakın basınç dayanımları SÇ+HSK numunesinde bulunmuştur. Sırasıyla 7 ve 28 günlük numunelerin basınç dayanımları 46,68 MPa ve 65,12 MPa'dır. SÇ+P numunesinin 7 ve 28 günlük basınç dayanımları $11,12 \mathrm{MPa}$ ve $18,45 \mathrm{MPa} ; \quad \mathrm{SCC}+\mathrm{AEUK}$ 'nün $5,82 \mathrm{MPa}$ ve 9,90 MPa; SÇ+AT'nın 2,73 MPa ve 4,65 MPa'dır. En düşük değer ise SÇ+MT numunesinde olup $1,0 \mathrm{MPa}$ ve $2,73 \mathrm{MPa}$ çıkmıştır. Şekil 11'de SÇ numunesinin oda sıcaklığında, kür tankında ve $100{ }^{\circ} \mathrm{C}, 500{ }^{\circ} \mathrm{C}, 1000{ }^{\circ} \mathrm{C}$ yüksek sicaklıklı etüvde bekletilen numunelerin basınç dayanımları incelendiğinde diğer numunelerin aksine su içinde bekletilenlerin 7 günde 28 günlüklere göre daha yüksek çıktığı saptanmıştır. Bu değerler sırasıyla 22,88 $\mathrm{MPa}$ ve 15,50 MPa'dır. 28 günlük numunenin 7 güne göre düşüş oranı \%32 dolayındadır. $\mathrm{Bu}$ sonuç $\mathrm{SÇ}$ numunelerinin su içinde dayanım kaybettiğini göstermektedir. En yüksek basınç dayanımı $100{ }^{\circ} \mathrm{C}$ bekletilen numunelerde elde edilmiştir. 7 ve 28 günlük dayanım değerleri sırasıyla $61,23 \mathrm{MPa}$ ve 79,15 MPa'dır. 28 günlük numunelerin dayanımları 7 güne göre yaklaşık \%29 artmıştır. $500{ }^{\circ} \mathrm{C}$ 'de çok küçük değerler elde edilirken, $1000{ }^{\circ} \mathrm{C}$ 'de numuneler dağılmış ve dayanım bulunamamıștır. Weber ve arkadaşları (2012) yaptığı çalışmada SÇ ile bazı dolgu malzemelerinin beraber kullanılması neticesinde yüksek basınç dayanımına sahip harç numuneleri elde edildiği belirtilmiștir [25]. Smith-Johannsen (1982) yaptığı çalışmada, SÇ normal Portland çimentosuna göre yanmaya ve 1sıya karş1 direncinin oldukça fazla olduğu görülmüştür [21]. Santra ve arkadaşları (2009) yaptıkları çalışmada SÇ numunelerinin yüksek sıcaklıkta stabil olduklarını gözlemlemişlerdir [23]. Gürbüz ve Kork (2020), geleneksel olarak kullanılan yap1 levhalarının yerine $\mathrm{MgO}$ levhaların kullanılmasının yangına dayanımının yüksek ve çevre dostu olmasından dolayı tercih edilebilir sonucuna varmıştır [7]. Austin ve Daniel (1949), Smith-Johannsen (1980) (1982), Moraitou (1994), Öztürk ve arkadaşları (2008) ve Gürbüz ve Kork (2020) yapmış oldukları çalışmalarda SÇ ile üretilen numunelerin suya karşı dirençlerinin oldukça zayıf, yüksek nemli ortamlarda 
numunelerin deformasyona uğradığı bu sebeple numune dayanımlarının olumsuz etkilendiği görülmüştür [20,21,26,22,7].

Bulunan dayanım sonuçlarının literatür ile uyumlu olduğu saptanmıştır. Bu sonuçlara göre referans numunelerin dayanım değerlerinin oldukça yüksek çıktığı, karışım içerisine ikame edilen katkı maddelerinin cinsine göre numune dayanım değerlerinde düşüşler görülmüştür. Karışım içerisine ikame edilen; HSK maddesinin karışım içerisine bir miktar hava sürüklemesi, P katkı maddesinin ise boşluklu ve gözenekli bir yapıda olması referans numuneye göre dayanım değerlerinde düşüşlerin meydana gelmesine neden olduğu düşünülmektedir. SÇ+AEUK ve SÇKT numunelerinde zamanla gözle görülür bir şekilde çatlakların oluşmasının dayanım düşüklüğüne sebep olduğu düşünülmektedir. Ayrıca SÇKT numunesinin 7 günlük dayanım değerlerinin 28 günlük dayanım değerlerinden yüksek olması SÇ numunelerinin suya karşı direncinin zayıf olduğunu göstermektedir. Dolayısıyla yüksek nemli ortamın SÇKT numune dayanımlarını olumsuz etkilediği düşünülmektedir.

\subsection{Birim Hacim A ̆ğırlık}

Numunelerin birim hacim ağırlık deney sonuçları Şekil 12'de verilmiştir. Şekil 12'deki birim hacim ağırlık değerleri üç adet deneyin ortalaması alınarak bulunmuştur.

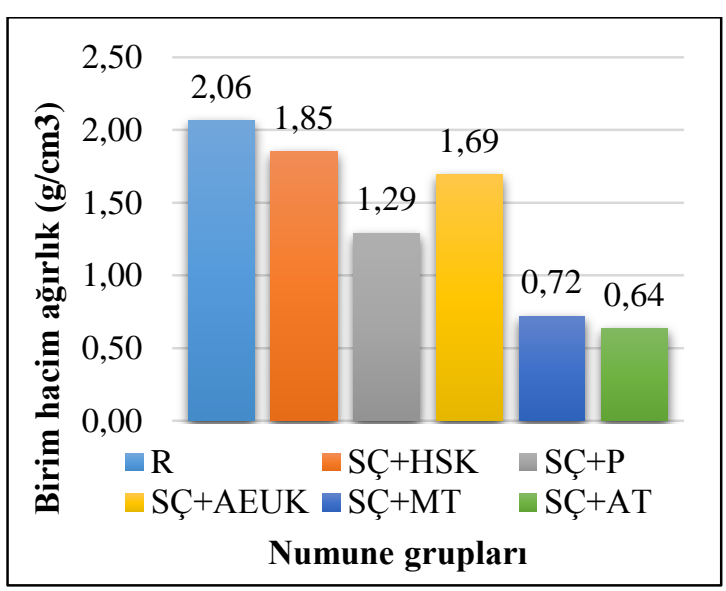

Şekil 12. Birim hacim ağırlıkları
Şekil 12'de verilen değerler incelendiğinde, en yüksek birim hacim ağırlık değerinin $2,06 \mathrm{~g} / \mathrm{cm}^{3}$ ortalama ile $\mathrm{R}$ numunelerinde olduğu görülmektedir. HSK katkısının birim hacim ağırlık değerini yaklaşık \%10, AEUK ikamesinin yaklaşık $\% 18$, P maddesinin yaklaşık \%37, MT maddesinin yaklaşık \%65, AT maddesinin yaklaşık \%69 azalttı̆gı görülmüştür. SÇ+HSK, SÇ+AEUK, $\mathrm{SÇ}+\mathrm{P}, \mathrm{SÇ}+\mathrm{MT}$ ve SÇ+AT numunelerinin birim hacim ağırlık değerleri sırasıyla $1,85 \mathrm{~g} / \mathrm{cm}^{3}$, $1,69 \mathrm{~g} / \mathrm{cm}^{3}, 1,29 \mathrm{~g} / \mathrm{cm}^{3}, 0,72 \mathrm{~g} / \mathrm{cm}^{3}$ ve $0,64 \mathrm{~g} / \mathrm{cm}^{3}$ olduğu görülmektedir.

Karışım içerisine ikame edilen; HSK maddesinin karışım içerisine bir miktar hava sürüklemesi, $\mathrm{P}$ katkı maddesinin ise boşluklu ve gözenekli bir yapıda olması referans numuneye göre birim hacim ağırlık değerlerinde düşüşlere neden olduğu düşünülmektedir. Kullanılan Sorel çimentosuna kıyasla AEUK, MT ve AT katkı maddelerinin özgül ağırlıklarının düşük olması bu katkı maddeleri ile üretilen numunelerin birim hacim ağırlıklarının da düşük olmasına neden olmuştur.

\subsection{Su Emme ve Görünür Gözeneklilik Deney Sonuçları}

Numunelerin su emme ve görünür gözeneklilik deney sonuçları sırasıyla Şekil 13 ve Şekil 14'de verilmiştir. $\mathrm{Su}$ emme ve görünür gözeneklilik deney sonuçları üç adet deneyin ortalaması alınarak bulunmuştur.

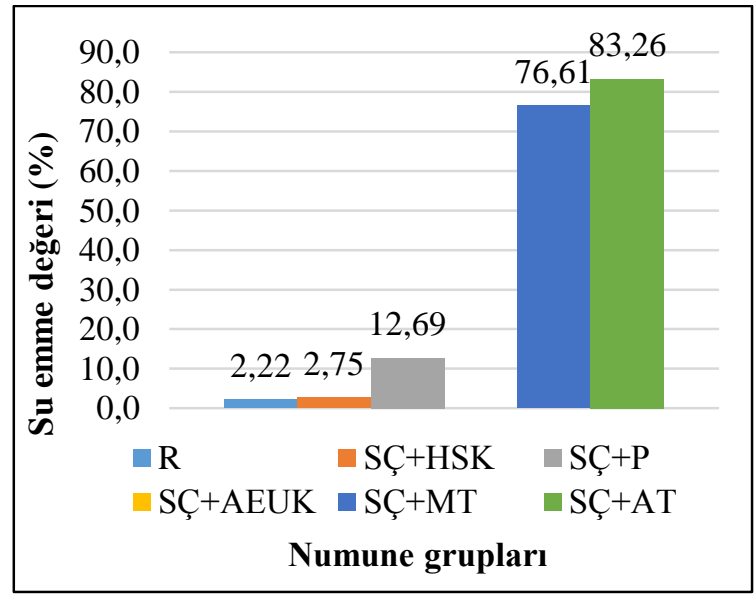

Şekil 13. Su emme değerleri 
Şekil 13 'te verilen değerler incelendiğinde $\% 2,22$ ortalama ile en düşük su emme değerlerinin $\mathrm{R}$ numunelerinde olduğu görülmüştür. SÇ+HSK numunelerinin su emme oranı \%2,75'tir. Bu değer $\mathrm{R}$ numunesinin su emme oranından \%24 fazladır. SÇ+P numunelerinin su emme oranı \%12,69'dur. En yüksek su emme oranı $\mathrm{SÇ}+\mathrm{AT}$ numunelerinde $\% 83,26$, en yüksek ikinci ise \%76,61 ile SÇ+MT numunelerindedir.

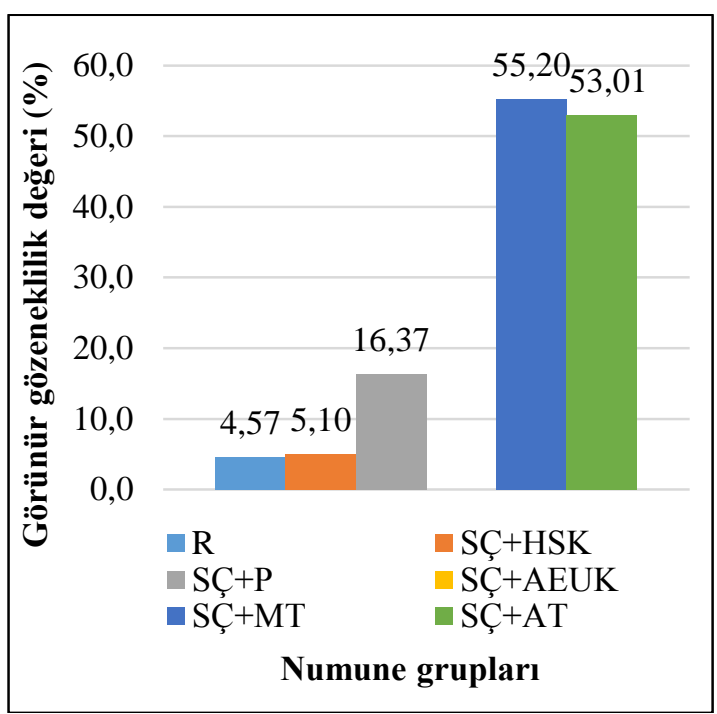

Şekil 14. Görünür gözeneklilik değerleri

Şekil 14'te verilen değerler incelendiğinde; \%4,57 ortalama ile en düşük görünür gözeneklilik değerlerinin $\mathrm{R}$ numunelerinde, \%55,20 ortalama ile en yüksek SÇ+MT numunelerinde olduğu görülmektedir. SÇ+HSK numunesinde görünür gözeneklilik oranı $\% 5,10, \mathrm{SC}+\mathrm{P}$ numunesinde $\% 16.37$, SÇ+AT numunesinde $\% 53,01$ 'dir.

Ahşap talaşı, mısır koçanı talaşı ve puzolanik maddelerin boşluklu yapıda olması; HSK maddesinin karışım içerisine bir miktar hava sürüklemesi sebebiyle SÇ+HSK numunesinin daha boşluklu bir yapıda olması numunenin su emme oranlarını ve görünür gözeneklilik değerlerini artırmıştır. SÇ+AEUK numunelerinin su içerisinde dağılması nedeniyle su emme oranları ve görünür gözeneklilik değerleri bulunamamıştır.

\subsection{Hızlandırılmış Harç Çubuğu Deney Sonucu}

Numunelerin hızlandırılmış harç çubuğu deney sonuçları Şekil 15 'te verilmiştir. Hızlandırılmış harç çubuğu deney sonuçları üç adet deneyin ortalaması alınarak bulunmuştur.

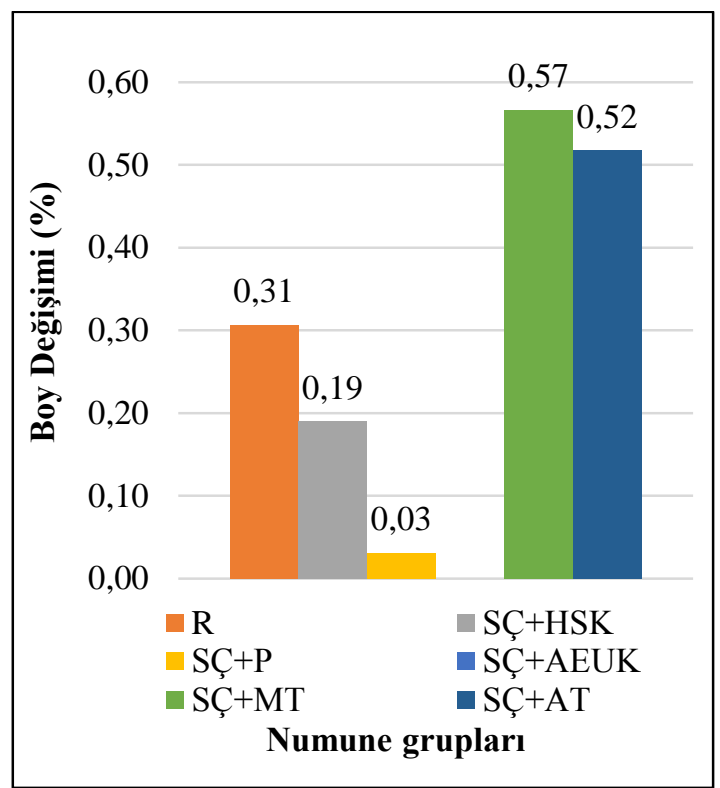

Şekil 15. Hızlandırılmış harç çubuğu

Şekil 15 'teki veriler incelendiğinde en düşük boy değişimi $\mathrm{SÇ}+\mathrm{P}$ numunesinde $\% 0,03$ bulunmuştur. İkinci en düşük SÇ + HSK numunesinde $\% 0,19, \mathrm{R}$ numunesinde \%0,31 ve en fazla genleşme SÇ+MT numunesinde \%0,57 bulunmuştur. SÇ+AEUK numunelerinin su içerisine konulduktan bir süre sonra dağılmasından dolayı bu numunelerin boy değişimi değerleri ölçülememiştir. Sonuçların; R, SÇ+HSK， SÇ+MT ve SÇ+AT numunelerinde ASTM C 1260 standardına göre 14 günlük boy değişiminin maksimum sınırı olan $\% 0,1$ 'in üstünde bir değerde olduğu görülmüştür.

$\mathrm{R}$ numuneye göre $\mathrm{SÇ}+\mathrm{HSK}$ ve $\mathrm{SÇ}+\mathrm{P}$ numunelerinin $\mathrm{Na}(\mathrm{OH})$ çözeltili suya karş1 dirençlerinin arttı̆̆ gözlemlenmiştir. $\mathrm{Bu}$ direnç artışının ikame edilen HSK ve P katkı maddeleri sayesinde olduğu özellikle SÇ ile $\mathrm{P}$ katkı 
maddesinin oldukça iyi uyumluluk gösterdiği tespit edilmiştir.

\subsection{Ultrases Geçiş Hızı Deney Sonucu}

Numunelerin ultrases geçiş hızı deney sonuçları Şekil 16'da verilmiştir. Ultrases geçiş hızı deney sonuçları üç adet deneyin ortalaması alınarak bulunmuştur.

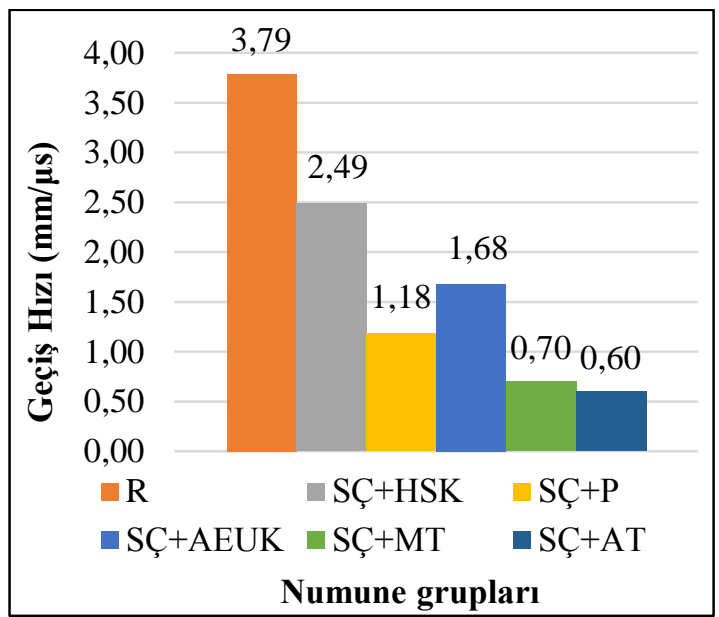

Şekil 16. Ultrases geçiş hızları

Şekil 16'da verilen değerler incelendiğinde 3,79 $\mathrm{mm} / \mu$ s ortalama ile en yüksek ultrases geçiş hızı değerlerinin $\mathrm{R}$ numunelerinde olduğu görülmüştür. $2,49 \mathrm{~mm} / \mu$ s ile ikinci en yüksek ultrases geçiş hızı değeri SÇ+HSK numunesinde olduğu ve R numunesine göre ultrases geçiş hızı değeri yaklaşık \%35 azaldığı görülmüştür. SÇ+AEUK, $\mathrm{SÇ}+\mathrm{P}, \mathrm{SÇ}+\mathrm{MT}$ ve SÇ+AT numunelerinin ultrases geçiş hızı değerleri sırasıyla $1,68 \mathrm{~mm} / \mu \mathrm{s}, 1,18$ $\mathrm{mm} / \mu \mathrm{s}, \quad 0,70 \mathrm{~mm} / \mu \mathrm{s}$ ve $0,60 \mathrm{~mm} / \mu \mathrm{s}$ olduğu görülmektedir. R numunesine kıyasla SÇ içerisine; AEUK ikamesinin ultrases geçiş hızı değerini yaklaşık \%56, P maddesinin yaklaşık \%69, MT maddesinin yaklaşık \%82, AT maddesinin yaklaşık \%84 azalttığı görülmüştür.

SÇ ile kullanılan katkı maddelerinin ses yalıtımına pozitif bir katkı sağladığı görülmüştür. Karışım içerisine ikame edilen; HSK maddesinin karışım içerisine bir miktar hava sürüklemesi, P katkı maddesinin ise boşluklu ve gözenekli bir yapıda olması nedeniyle referans numuneye göre ultrases geçiş hızı değerlerinde düşüşler sağlamıştır. Ayrıca karışım içerisinde MT ve AT katkı maddelerinin kullanılmasının ultrases ses geçiş hızlarını büyük oranda düşürdüğü bu sebeple bu iki katkının karışımda kullanılmasının ses yalıtımı açısından önemli olduğu düşünülmektedir.

\subsection{Isı İletim Katsayısı Deney Sonucu}

Numunelerin 1sı iletim katsayısı deney sonuçları Şekil 17'de verilmiştir. Isı iletim katsayısı deney sonuçları üç adet deneyin ortalaması alınarak bulunmuştur.

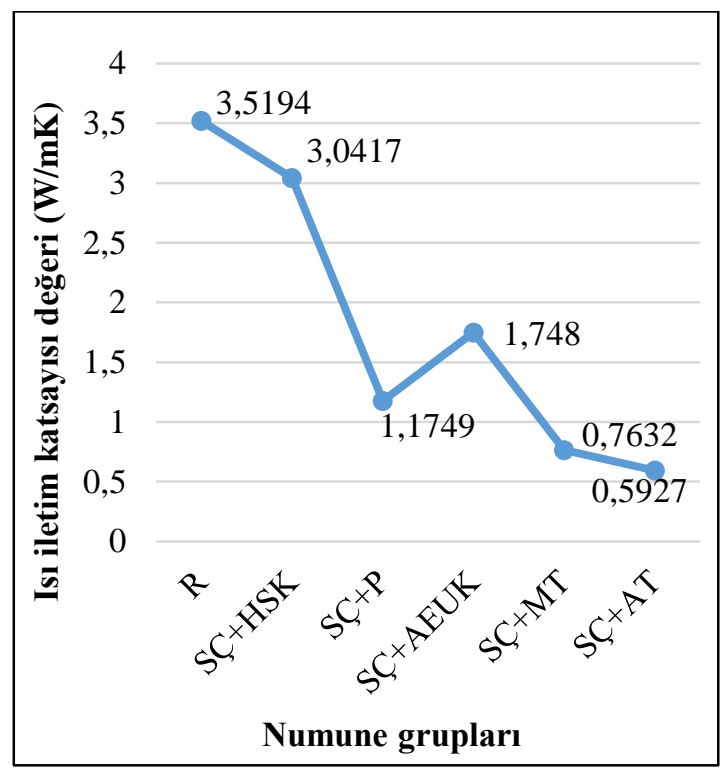

Şekil 17. Isı iletim katsayıları

Şekil 17'de verilen değerler incelendiğinde 3,5194 $\mathrm{W} / \mathrm{mK}$ ortalama ile en yüksek 1s1 iletim katsayıs1 değerinin $\mathrm{R}$ numunelerinde olduğu görülmüştür. HSK katkısının 1S1 iletim katsayısı miktarını yaklaşık \%14, AEUK ikamesinin yaklaşık \%50, P maddesinin yaklaşık \%67, MT maddesinin yaklaşık \%78, AT maddesinin yaklaşık \%83 azalttığı görülmüştür. SÇ+HSK, SÇ+AEUK, $\mathrm{SÇ}+\mathrm{P}, \mathrm{SÇ}+\mathrm{MT}$ ve $\mathrm{SÇ}+\mathrm{AT}$ numunelerinin $1 \mathrm{~s}$ 1 iletim katsayısı değerleri sırasıyla $3,0417 \mathrm{~W} / \mathrm{mK}$, $1,748 \mathrm{~W} / \mathrm{mK}, 1,1749 \mathrm{~W} / \mathrm{mK}, 0,7632 \mathrm{~W} / \mathrm{mK}$ ve $0,5927 \mathrm{~W} / \mathrm{mK}$ olduğu görülmektedir. 
SÇ ile kullanılan katkı maddelerinin 1sı iletim katsayısı değerlerini düşürdüğü tespit edilmiştir. Karışım içerisine ikame edilen; HSK maddesinin karışım içerisine bir miktar hava sürüklemesi, P katkı maddesinin ise boşluklu ve gözenekli bir yapıda olması nedeniyle referans numuneye göre ısı iletim katsayısı değerlerinde düşüşler sağlamıştır. Ayrıca karışım içerisinde MT ve AT katk1 maddelerinin kullanılmasının 1S1 iletim katsayılarını büyük oranda düşürdüğü bu sebeple bu iki katkının karışımda kullanılmasının 1sı yalıtımı açısından önemli olduğu düşünülmektedir.

\subsection{BET Yüzey Alanı Analizi}

Numunelerin BET yüzey alanı analiz sonuçları Şekil 18'de verilmiştir. BET yüzey alanı deney sonuçları üç adet deneyin ortalaması alınarak bulunmuştur.

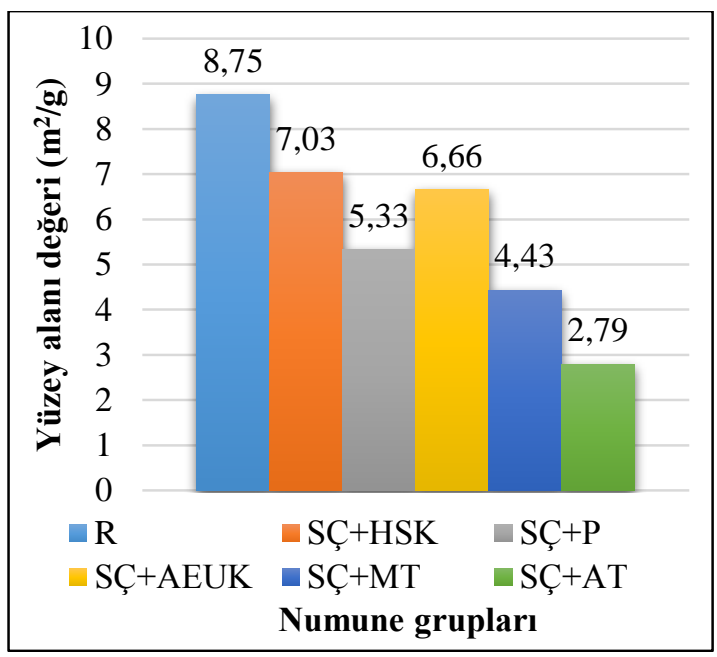

Şekil 18. BET yüzey alanı analizleri

Şekil 18'de verilen değerler incelendiğinde 8,75 $\mathrm{m}^{2} / \mathrm{g}$ ortalama ile en yüksek BET yüzey alanı değerinin $\mathrm{R}$ numunesinde olduğu görülmüştür. HSK katkısının BET yüzey alanı değerini yaklaşık $\% 20$, AEUK ikamesinin yaklaşık \%24, P maddesinin yaklaşık \%39, MT maddesinin yaklaşık \%49, AT maddesinin yaklaşık \%68 azalttığ 1 görülmüştür. SÇ+HSK, SÇ+AEUK, $\mathrm{SÇ}+\mathrm{P}, \mathrm{SÇ}+\mathrm{MT}$ ve $\mathrm{SÇ}+\mathrm{AT}$ numunelerinin BET yüzey alanı değerleri sirasıyla 7,03 $\mathrm{m}^{2} / \mathrm{g}, 6,66$ $\mathrm{m}^{2} / \mathrm{g}, 5,33 \mathrm{~m}^{2} / \mathrm{g}, 4,43 \mathrm{~m}^{2} / \mathrm{g}$ ve $2,79 \mathrm{~m}^{2} / \mathrm{g}$ olduğu görülmektedir.

Elde edilen bulgulara göre referans numunesinin BET yüzey alanı değerlerinin yüksek olduğu saptanmıştır. Karışım içerisine ikame edilen katkı maddelerinin türüne göre BET yüzey alanı değerlerinde düşüşler görülmüştür.

\section{SONUÇ}

Hazırlanan altı farklı karışım numunelerine uygulanan eğilme ve basınç dayanımı testleri neticesinde; eğilme ve basınç dayanım değerlerinin en yüksek $\mathrm{R}$ numunelerinde, en düşük $\mathrm{SÇ}+\mathrm{MT}$ numunelerinde olduğu gözlemlenmiştir.

R numunelerinin bulunduğu ortam sıcaklığının artması eğilme ve basınç dayanımı değerlerine 100 ${ }^{\circ} \mathrm{C}$ sicaklığa kadar pozitif bir etkide bulunurken belirli bir sicaklıktan sonra ise dayanım değerlerinde düşüşe hatta numunelerde parçalanmalara neden olduğu görülmüştür.

Kür tankında bekletilen numunelerin bekleme süresiyle numuneler üzerinde meydana gelen çatlakların orantılı olduğu, oluşan bu çatlakların zamanla numunelerin eğilme ve basınç dayanımlarında önemli miktarda düşüşlere neden olduğu düşünülmektedir. $\mathrm{Bu}$ sebeple Sorel çimentolu malzemelerin sudan ve yüksek nemli ortamdan korunması önerilmektedir.

R karışımların priz sürelerinin kısa olduğu tespit edilmiştir. Karışım içerisine ikame edilen katkı maddeleri sayesinde bu priz sürelerinin uzatılabileceği düşünülmektedir.

R karışımlarından elde edilen numunelerin belirli bir sıcaklığa kadar oldukça dirençli olduğu saptanmıştır. Bu sebeple sıcaklığın yüksek olduğu ortamlarda Sorel çimentolu karışımların kullanılması önerilebilir.

Elde edilen bulgular neticesinde; $\mathrm{R}$ numunesine kıyasla SÇ içerisine HSK, $\mathrm{P}$ ve endüstriyel atık malzemesi olan AEUK, MT ve AT malzemelerinin eklenmesiyle numunelerin yalıtım özelliklerinde 
iyileşmelerin meydana geldiği görülmüștür. Ancak eğilme ve basınç dayanımlarında düşüşe neden olmuşlardır.

\section{TEŞEKKÜR}

Bu çalışma, YLS 2019/6-13 no'lu proje kapsamında yapılmış olup Kahramanmaraș Sütçü İmam Üniversitesi Rektörlüğü BAP Koordinasyon Birimi tarafından desteklenmiştir.

\section{KAYNAKLAR}

1. Türkiye Mühendislik Haberleri, 2015. Binalarda Is1 Yalıtımı ve Is1 Yalitım Malzemeleri. https://www.imo.org.tr/resimler lekutuphane/pdf/17182_44_51.pdf. (Erişim Tarihi:11.03.2021).

2. Tatarczak, A., Fic, S., 2015. Additives in Sorel Cement Based Materials-impact Study. In Proceedings of the International Conference on Civil, Structural and Transportation Engineering, Ottawa, Canada, Paper (No. 318).

3. Özer, O., 1996. Türkiye'de Üretilen Kostik Kalsine Manyezitlerinin İncelenmesi ve Sorel Çimentosu Parametrelerinin Araştırılması. (Doctoral dissertation, Fen Bilimleri Enstitüsü).

4. Ring, T., Ping, E., 2007. Sorel Cement Reactions and Their Kinetics. In the 2007 AIChE Annual Meeting.

5. Chau, C.K., Li, Z., 2008. Microstructures of Magnesium Oxychloride Sorel Cement. Advances in Cement Research, 20(2), 85-92.

6. Shahbazı, B., Sadeghı, F.D., 2016. Investigation Physical Properties of Magnesium Oxychloride Cement (Sorel Cement).

7. Gürbüz, A., Kork, Y.E., 2020. Magnezyum Oksit (MgO) Levhalar Üzerine Bir Derleme. Sciennovation, 2(1), 29-38.

8. Özertaş Kimya Maden, 2021. Magnezyum Oksit Kimyasal ve Fiziksel Analiz. https://ozertas.com.tr/tr/pages/sinter-manyezitmadeni-ozertas-kimya-maden. (Erişim Tarihi:11.01.2021).

9. Türker, P., Erdoğan, B., Katnaş, F., Yeğinobalı, A., 2009. Türkiye'deki Uçucu Küllerin
Sınıflandırılması ve Özellikleri. Türkiye Çimento Müstahsilleri Birliği, 20-34.

10. Maden Tetkik ve Araştırma Genel Müdürlüğü, Tipik Pomza Mineralini Oluşturan Özellikler. https://www.mta.gov.tr/v3.0/bilgimerkezi/pomza\#: :text=G\%C3\%B6zenekler\% 20aras\%C4\%B1\%20genelde\%20ba\%C4\%9Fla nt\%C4\%B1s\%C4\%B1z\%20bo\%C5\%9Fluklu, $\% 2 \mathrm{C} \% 20$ pek\%C5\%9F\%2Dtayn)\%20ayr\%C4 \%B11\%C4\%B1r. (Erişim Tarihi:25.02.2021)

11. Basf, MasterAir 200 Teknik Bilgi Föyü. https:/www.izoagra.com/images/uploads/bayi/ dosya/masterair-200_56E782.pdf. (Erişim Tarihi:03.03.2021).

12. Jurišová, J., Fellner, P., Pach, L., 2015. Characteristics of Sorel Cement Prepared from Impure Materials. Acta Chimica Slovaca, 8(2), 87-90.

13. TS EN 196-3, 2017. Çimento Deney Yöntemleri-Bölüm 3: Priz Süreleri ve Genleşme Tayini, Türk Standartları Enstitüsü, Ankara.

14. TS EN 772-13, 2002. Kağir Birimler- Deney Metotlar1-Bölüm 13: Kagir Birimlerin Net ve Brüt Kuru Birim Hacim Kütlelerin Tayini (Doğal Taş Hariç), Türk Standartları Enstitüsü, Ankara.

15. TS EN 993-1, 2020. Yoğun Refrakter Mamuller için Deney Metotları-Kısım 1: Kaba Yoğunluk, Görünür Porozite ve Hakiki Porozitenin Tayini.

16. TS EN 196-1, 2016. Çimento Deney MetotlarıBölüm 1: Dayanım Tayini, Türk Standartları Enstitüsü, Ankara.

17. ASTM C1260-14, Standard Test Method for Potential Alkali Reactivity of Aggregates (Mortar-Bar Method)

18. ASTM C597-16, 2016. Standard Test Method for Pulse Velocity Through Concrete, ASTM International, West Conshohocken, PA.

19. ASTM C 1113-90, Test Method for Thermal Conductivity of Refractories by Hot Wire (Platinum Resistance Thermometer Technique).

20. Austin, L. W., Daniel, R., 1949. U.S. Patent No. 2,466,145. Washington, DC: U.S. Patent and Trademark Office. 
21. Smith-Johannsen, R., 1982. U.S. Patent No. 4,352,694. Washington, DC: U.S. Patent and Trademark Office.

22. Öztürk, A., Timuçin, M., Göktaş, A., Özer, S.M., 2008. GRE Esaslı Seramik Karoların Yüzeylerinin Parlatılmasında Kullanılabilecek Kompozit Parlatma Disklerinin Üretimi, ODTÜ Proje No: 105M140, 58.

23. Santra, A.K., Liang, F., Fitzgerald, R., 2009. Sorel Cement for HP/HT Downhole Applications. In SPE International Symposium on Oilfield Chemistry. Society of Petroleum Engineers, doi.org/10.2118/ 121102-MS.

24. Zhengyuan, Z., 1993. Sorel Cement Property Experiment and Improvment Study. Journal of China Three Gorges University (Natural Sciences), 02.

25. Weber, J., Bayer, K., Pintér, F., 2012. Nineteenth Century "Novel" Building Materials: Examples of Various Historic Mortars Under the Microscope. In Historic Mortars, Springer, Dordrecht, 89-103.

26. Moraitou, A., 1994. Meyer Cement and its Effect on the Propylaea Marble. In International Meeting $\left(4^{\text {th }}\right)$ on the Restoration of the Acropolis Monuments: English Summaries, 92-92. 